\title{
WAITING FOR THE LORD: THE FULFILMENT OF THE PROMISE OF LAND IN THE OLD TESTAMENT AS A SOURCE OF HOPE
}

\author{
Ntozakhe Simon Cezula \\ Department of Old and New Testament \\ Stellenbosch University
}

\begin{abstract}
This article examines the fulfilment of the land promise in the OT as a source of hope. This is particularly significant in our contemporary context in which land has become a contested issue. The question this article asks is whether the fulfilment of the land promise in the OT can be a source of hope for communities in (South) Africa. In the process of dealing with the question, the article observes that there are different theological interpretations to the Abrahamic promise within the Bible. Premising its line of thought on this observation, the hypothesis is advanced that some theological interpretations render the fulfilment of the land promise a source of despair for some communities in South Africa while others make it a source of hope. Specifically, Ezra-Nehemiah represents the former and the Isaiah tradition, the latter.
\end{abstract}

Key Words:Exclusivity; Hope; Inclusivity; Land; Particularism; ${ }^{1}$ Promise; Universalism ${ }^{2}$

\section{Introduction}

This article endorses Gordon J Wenham's description of Genesis as a story of the origins of the human race (1-11) and the origins of Israel (12-50). Wenham argues that the key theological themes of Genesis 12-50 and the whole Pentateuch are set out in 12:1-3. ${ }^{3}$ Additionally, the theological influence of Genesis 12:1-3 does not end in Genesis and the Pentateuch, but stretches throughout the Old Testament, as will be shown. Genesis 12 introduces a story of Abraham's family waiting for a land promised to Abraham as a home. The fulfilment of this promise became a source of hope for his descendants. It remains to be investigated whether fulfilment of this hope can be a resource for the present Christian communities in Africa in their sometimes dispiriting circumstances of landlessness. It is against this background that this essay will explore the theme of hope in the Old Testament which often becomes a case of hope in the midst of despair. Especially because promise creates ground for hope, attention will be given to the way the promise of land is portrayed in the Old Testament (OT) which is particularly significant in our contemporary context in which land has become a contested issue.

This introduction will be followed by a response to the question, "Who are Abraham's descendants?" The discussion will proceed to look more closely at "waiting for the Lord" and the fulfilment of the land promise. The books of Ezra-Nehemiah and Isaiah will then be

\footnotetext{
'Particularism' (Grisanti calls it nationalism) refers to God's redemptive blessings reserved for Israel alone. Grisanti, Israel's Mission, 44.

2 'Universalism' refers to God's redemptive blessings available for all peoples regardless of ethnicity. Grisanti, Israel's Mission, 44.

3 Wenham, Genesis, 55-56.
} 
examined with the intention to expose the reader to different theologies on the fulfilment of the land promise. Subsequent reading of the biblical theme of the land promise and its fulfilment in the colonial era will be explored cursorily. The conclusion will attempt to integrate the different phases under discussion.

\section{Fulfilment of the Land Promise in the OT as a Source of Hope}

The promises of progeny, blessing and land pronounced in Genesis 12 introduce each of the patriarchs' narratives. ${ }^{4}$ The fulfilment of these promises led to the emergence of a pattern whereby God is recognised as the faithful one whose promises are fulfilled. ${ }^{5}$ Consequently, the national consciousness of the Israelites found its most explicit expression in the patriarchal narratives' divine promises. ${ }^{6}$ Among these, the land promise occupies a crucial position. ${ }^{7}$ According to Walter Kaiser few issues are as important as that of the promise of the land to the patriarchs and the nation of Israel in the Old Testament. ${ }^{8}$ Van Seters propounds that "on the older level of the written tradition the Abraham story opened with the land promise alone (12:1 and 6-7)". ${ }^{9}$ Illuminating its importance, Brueggemann argues that biblical faith promises humanness that:

...will be found in belonging to that locus in which the peculiar historicity of a community has been expressed and to which recourse is made for purpose of orientation, assurance, and empowerment. ${ }^{10,}$

So important is the land promise theme to the Old Testament that Israel's national identity became inextricably intertwined with it. Brueggemann posits that the memory of the land transaction for the burial of Sarah in Genesis 23 "reassures exiles, those again made "strangers and sojourners" to an extent that "even the death of the mother is shaped to be an occasion for deep trust in the promise". ${ }^{11}$ Describing the success of the Babylonian exile returnees to establish themselves as Abraham's 'spiritual heirs', Jean-Louis Ska concludes by saying: "Over the course of their history, the people of Israel constantly seek new reasons in their tradition to live and to hope. ${ }^{12}$ This article supposes that land is a basic need to a nation's existence, so much that landlessness induces desperation. So, during the exile $^{13}$ the land promise sustained the Israelites' optimism. Memory of the promise of land

Gen. $12: 7 ; 26: 3 ; 28: 13$.

"The birth of Isaac was promised (Gen. 18:9-15) and fulfilled (21:1-2a), and the land that had been promised (12:7) was granted, beginning with the purchase of the field in Machpelah (23:2-20)". Wimmer, Promise, 2000:1085.

6 Weisman, National Consciousness, 1985:55.

7 Van Seters continues to argue that it is the later Yahwist who builds into this older theme the promise of numerous progeny and that only with the threat of extinction in the exile does the divine promise of numbers becomes important (1975:271). However, Williamson differs, arguing that "within the Abrahamic narrative itself, and indeed within the rest of the book of Genesis, more attention is focused on promises relating to Abraham's posterity than any other. ... Such an inference is clearly a logical one to draw, given that without descendants, there would be no one to inherit the land, nor would there be anyone through whom blessing could be mediated to other people(s)" (2000:101). All that said, there is certainly merit in Brueggemann's assertion that a sense of place is a primary category of faith and an urgent hunger among people (2002:4).

Kaiser, The Promised Land, 1981:302.

Van Seters, Abraham, 1975:271.

Brueggemann, The Land, 2002:5.

1 Brueggemann, Genesis, 1982:196-197. However, he also warns that such a reading goes beyond the explicit statement of the text; presuming a promise underlying the text.

12 Ska, Introduction, 2006:89.

13 Jer. 30:3. 
defied demoralising circumstances signalling landlessness and revitalised waning hope. During the post-exilic period the land promise kindled the faith and continuing hope of the returned exiles. $^{14}$ It remained an unfading source of hope. Waiting for the Lord, the descendants of Abraham found hope in the fulfilment of the promise of the land in the Old Testament. Let us now investigate who are the descendants of Abraham who derive hope in the fulfilment of the land promise.

\section{Who are Abraham's Descendants?}

Biologically, Abraham had Ishmael ${ }^{15}$ as his first son, ${ }^{16}$ Isaac as his second son ${ }^{17}$ and six other children with Keturah, ${ }^{18}$ his concubine. ${ }^{19}$ "Everything he owned Abraham left to his son Isaac. But while he was still alive, Abraham gave gifts to the sons of his concubines and sent them off to the east, away from his son Isaac". ${ }^{20}$ So, "aside from Isaac, Sarah's only child, the fate of all of Abraham's children was to be sent into the Arabian Desert where they became the eponymous ancestors of Arab tribes". ${ }^{21}$ In Genesis 26:3 God repeats to Isaac the land promise He made to Abraham. Isaac therefore becomes the promised offspring through whom God keeps the covenant made with Abraham in Genesis 12:7. Isaac fathered two sons, Esau ${ }^{22}$ and Jacob. ${ }^{23}$ In Genesis 28:13, again, God repeats the promise He made to Abraham and Isaac, making Jacob the promised offspring through whom God keeps the covenant. Jacob's twelve sons became eponymous ancestors of the twelve tribes of Israel. As the descendants of Abraham, they were beneficiaries of the land promise.

In 1 Kings 11-12, due to Solomon's disobedience to the covenant, Israelite identity was launched into a new set of circumstances to which it had to adapt. An epochal schism took place in the united kingdom of Israel. The twelve tribes split into the two tribes ${ }^{24}$ named after Judah $^{25}$ and the ten tribes which inherited the name Israel. The Israelite identity as Abraham's descendants became a contentious issue. Both the kingdom of Judah and the kingdom of Israel claimed to be the rightful heirs to the Abrahamic promise. Because of persistent disobedience to the covenant, the northern kingdom of Israel was destroyed ${ }^{26}$ by the Assyrians ${ }^{27}$ and later ${ }^{28}$ the southern kingdom of Judah by the Babylonians. ${ }^{29}$ The OT says little about the ten tribes after the Assyrian exile. During the approximately one

14 Neh. 9:7-8.

15 He is the eponymous ancestor of the Ishmaelites. In Gen. 25:16 Ishmael's sons are referred to as

"twelve princes according to their tribes."

16 Gen. 16:15.

17 Gen. 21:2-3.

18 One of them was Midian, an eponymous ancestor of the Midianites.

19 Gen. 25:1. McCarter summarises it as follows: "Abraham's own descendants fall into three groups: those descended from Ishmael (Ishmaelites or Arabs), those descended from Isaac (Edomites and Israelites), and those descended from the various sons of Keturah (a collateral line of Arabs)" (2000:10). Genesis 25:5-6.

Phelps, Midian, 896.

Eponymous ancestor of the Edomites (Gen. 36)

Also called Israel, he is the eponymous ancestor of the Israelites (Gen. 25:19-26).

They are Judah and Benjamin.

He is the fourth son of Jacob and Leah (29:35).

Ca.721 BC. Cf. Wills, Not God's People, 55.

2 Kings 17:6.

ca. $586 \mathrm{BC}$.

2 Kings 25:8-11. 
hundred and thirty five years between the Assyrian exile and the Babylonian exile, Judah monopolised the identity of being Abraham's descendants. However, during the Babylonian exile, again, Israelite identity was plunged into another new circumstance of a national split. The term 'Israel' was claimed by both the Judean exiles and the Judean remainees as each being the rightful heir to the Abrahamic land promise. ${ }^{30}$ This contestation reached its climax in the Ezra-Nehemiah ${ }^{31}$ narrative, after the return from the Babylonian exile.

At this juncture it is imperative to place the above-outlined contestations over Abrahamic descent into perspective. This literature deals mostly with pre-monarchic (Pentateuch) and monarchic events (1 Samuel - 2 Chronicles) while the final forms are exilic and post-exilic. This means the narratives depicting another historical period are told in response to the challenges of another period. So far we have so far been dealing with the time of the text. However, the Abrahamic memory in these narratives actually provides important theo-political viewpoints of the Second Temple period. To borrow from Brueggemann's (1979) wisdom, this literature is not "sociologically disinterested nor singularly concerned with matters theological". It reflects pivotal socio-economic and political concerns. ${ }^{32}$ Against this background it is time to review the text to discern circumstances that could have affected the thought-patterns of the authors. This will be done by examining the social conditions of the exilic and the post-exilic times in which the texts were written and by examining books reflecting thought-patterns of the time. Firstly, however, let us briefly examine the concept "waiting for the Lord".

\section{'Waiting for the Lord'}

In the thirteenth chapter of his book, David W Henderson describes waiting as follows:

We see waiting in horizontal terms - a delay in our forward progress. We measure waiting in miles and minutes that stand between us and our goal. But waiting in biblical perspective is vertical - depending upon God in our shortfall. It is measured in terms of posture, not progress - yielding, relinquishing, trusting in him rather than relying in ourselves. From this perspective, waiting is the strong stand of hope, the muscular confidence of faith. ${ }^{33}$

From Henderson's description we can see that from a biblical perspective, there is an inextricable link between waiting, hope and faith. ${ }^{34}$ So, the article argues that to discern the essence of the phrase waiting for the Lord we need to engage with it in relation to hope and faith. Expressing this inextricable link, Jeffrey S Lamp declares that hope contributes significantly to the worldview of biblical faith and is manifested in quiet waiting before the Lord. ${ }^{35}$ In other words, waiting manifests hope which strongly influences the worldview of

Cf. Jer. 24; Ezek. 11:14-21 \& 33:23-29.

31 An extensive discussion on Ezra-Nehemiah was conducted in my unpublished dissertation; Identity Formation and Community Solidarity: Second Temple Historiographies in Discourse with (South) African Theologies of Reconstruction.

32 Brueggemann, Trajectories, 162.

33 Henderson, Tranquillity, 167.

34 This sentiment is expressed by Reumann when discussing faith, asserting that "in the OT, along with 'äman, terms like bātah ('trust; be confident, secure'), qāwâ ('hope'), yāhal and hâak̂a (both 'wait in hope') come into consideration" (Reumann, Faith, 453). 
biblical faith. This statement is the centrepiece of the idea underlying this examination of waiting for the Lord and the fulfilment of the land promise.

In Lamp's exact words “... the biblical understanding of hope is a much deeper concept that contributes significantly to the worldview of biblical faith". ${ }^{36}$ Ronald Simkins asserts that "the worldview of the Israelites included assumptions about the self and its relation to other selves..."37 The logical conclusion is that what the Israelites hoped for could influence their relations with other groups of people. Put differently, the way they interpreted the land promise and thus its fulfilment could have had a bearing on how they interacted with other nations. The article argues that there were different understandings of the land promise, which led to different expectations of the fulfilment and thus different approaches to foreigners. Let us attempt to establish the veracity of this assertion by examining Ezra-Nehemiah on the one hand and Isaiah on the other.

\section{Different Voices during and after the Babylonian Exile?}

When dealing with the issue about Abraham's descendants above, we were actually dealing with the world in the text. This section intends to explore the world of the text, viz., the social conditions of the authors. According to Dalit Rom-Shiloni "the exiles in Babylon continued to negotiate their status in relation to Judeans remaining in the land of Israel, rather than in relation to 'proximate others' - the diverse national groups present in Babylon". ${ }^{38}$ Describing the situation in exile Fanie Snyman argues that there was bitterness among the exiles toward those who had stayed behind. ${ }^{39}$ Daniel Smith-Christopher observes that "the separation of the community in 597-586 began to create long-standing divisions that persisted after groups of diaspora Jews returned to Palestine under Persian patronage". ${ }^{40}$ Remarking about what the prophets had to say concerning the remnant, Kenneth D Mulzac posits that, for Jeremiah and Ezekiel, the exiles constitute the true remnant since they carry the election promises and those left in Judah comprised an insignificant, poor assemblage. ${ }^{41}$ The exiles even conjured up an ideological strategy of the 'empty land' ideology to delete the remainees from the history of Judah. ${ }^{42}$ The mere existence of non-deported Yehudite Yahwists could be obscured by the presentation of the land as empty. ${ }^{43}$ According to Ska, this is the context of the production of the Abraham story. He places both Genesis 12-25 and Genesis 12:1-3 in context by arguing that the Abraham narrative ${ }^{44}$ is organised around the central issue: who will inherit the promise? He argues later that the aim of Genesis 12:1-3 was to show that Abraham is the ancestor of the exiled people who returned from Babylon to Israel and to legitimise their rights in the eyes of the people who had remained in the country. ${ }^{45}$ The Abraham narrative thus provided a

36 Lamp, Hope, 605.

37 Simkins, Worldview, 1387. Simkins further indicates that "the Israelites defined the self in collective terms... The person's social behaviour is largely determined by the goals of the group" (1388).

Smith-Christopher, Exile, 440.

Mulzac, Remnant, 1118.

42 Cf. Rom-Shiloni 2011:142-144; Lipschits 2005:119; Davies 2005:136; Seitz 1989:278-279. Bustenay Oded, however, rejects the idea of the "empty land myth" arguing that it is unproved and unnecessary. According to him, there is no point in inventing a myth of the empty land because, from the biblical writers ' point of view, the exiles returned to their home and repossessed their property (2003:71).

43 Kessler, Persia's Loyal Yahwists, 110.

44 Genesis 12-25.

45 Ska, Introduction, 89. 
framework for a land theology in post-exilic Yehud. Let us now examine the interaction between hope and faith in Ezra-Nehemiah.

\section{Ezra-Nehemiah}

Ezra 10:2-3 can give us a glimpse into how the land promise is interpreted in EzraNehemiah and how faith and hope affect each other in that context. These verses are a response to Ezra's reaction to the news that the returnees took some of the non-returnee locals' daughters as wives for themselves and for their sons, "so that the holy race was intermingled with the local residents" ${ }^{46}$ He tore his tunic and his robe and ripped out some of the hair from his head and beard. ${ }^{47}$ While he was praying and confessing, weeping and throwing himself to the ground before the temple of God people came to address him. ${ }^{48}$

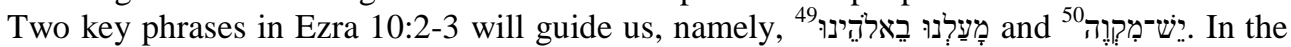
first phrase the first word means "we have acted unfaithfully" and the second one "to our God". They broke faith with their God. This unfaithful act was marrying foreign women from the peoples of the land. John Reumann refers to Martin Buber who distinguished OT/Judaic faith ('ěmûnâ) "as tribal, national, communal trust and fidelity, based on the covenant". "Marriage to women 'from the peoples of the land' constituted a serious breach of the covenant". 52 The second phrase means there is hope. Despite having acted unfaithfully, not all is lost, there is still hope. "Dealing with the offense opened a window of hope for the community". ${ }^{53}$ The solution was to cut a covenant with their God to send away all the women and their children, as Ezra advised them. What transpires here is that the covenant between God and Israel entails separation from foreigners. Interestingly, the land promise is part of the covenant. The fulfilment of this promise therefore involves separation from foreigners. The promise, its fulfilment and the accompanying hope in EzraNehemiah are understood in this light. Waiting for the Lord therefore meant also to separate from foreigners.

In Rom-Shiloni's discussion of an Ezra-Nehemiah ideological strategy she considers amalgamation to shed more light on this argument. The amalgamation ideological strategy amalgamates different nationalities into one group, resulting in the 'other' versus the exiles. This is the worldview that resulted from the mutual affection between hope and faith in Ezra-Nehemiah. The Judeans or Israelite-Yahwistic communities in the land are amalgamated in this one group to form what Ezra-Nehemiah refers to as "people(s) of the land $(s)$ " and thus employing a simple categorisation of the exiles vis-à-vis the people $(s)$ of the land(s) (including the groups from the northern tribes). Because it was upheld by the ruling class, this ideology was dominant during the early Second Temple period and it regarded only the exiles as the descendants of Abraham. In Joseph Blenkinsopp's words:

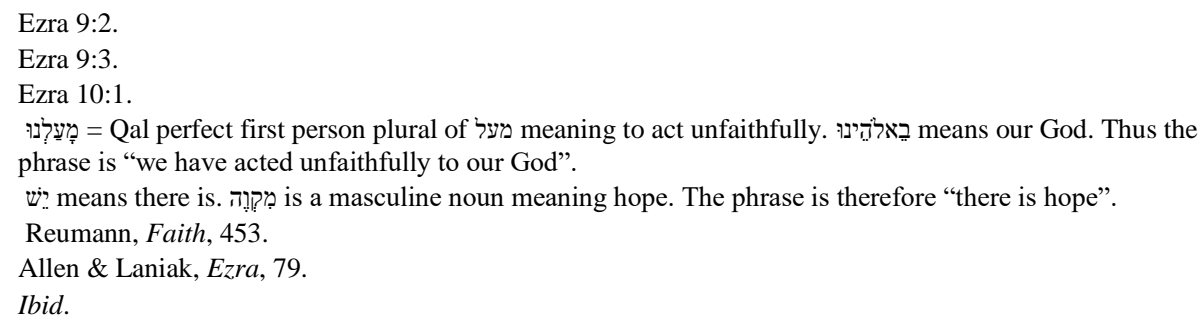


The claim to be the Israel which inherits the promises, commitments, and privileges to which the traditions testify was now limited to members of the golah who subscribed to its theology, its interpretation of the laws, and its religious practices. All other claims, including those of the inhabitants of Samaria, the Judeans who had never left the land, and presumably those elsewhere in the diaspora whose religious beliefs and practices differed from those of the golah leadership, were excluded. ${ }^{54}$

In Ezra-Nehemiah the Abrahamic land promise, claim or fulfilment was enfolded in this Babylonian exilic ideology of amalgamation. As the dominant group, Ezra-Nehemiah exiles claimed sole right to Abrahamic descent. A snippet from Nehemiah's activism for the amalgamation theological strategy may hint at the kind of behaviour that can be borne by the worldview and belief of this strategy. He noticed that of the men of Judah who had married women from Ashdod, Ammon, and Moab, ${ }^{55}$ half of their children spoke the language of one of the peoples mentioned and were unable to speak the language of Judah. ${ }^{56}$ In response, he called down a curse on them, struck some of the men and pulled out their hair. He then made them swear that they would never intermarry with those nations. ${ }^{57}$ Further addressing them, he stated as follows:

Was it not because of things like these that King Solomon of Israel sinned? Among the many nations there was no king like him. He was loved by his God, and God made him king over all Israel. But the foreign wives made even him sin! Should we then in your case hear that you do all this great evil, thereby being unfaithful to our God by marrying foreign wives? ? $^{58}$

Seeing that the return from exile was the fulfilment of the land promise and that it entailed the ideological strategy of amalgamation, as Rom-Shiloni has argued, it is not unreasonable to conclude that the vindication of the exiles was tantamount to the humiliation of the "people(s) of the land(s)". The Abraham narrative coated with the amalgamation theology thus provided a framework for a land theology in post-exilic Yehud that affirmed the exiles and negated the "people $(s)$ of the land $(s)$ ". The waiting of the exiles in its amalgamation form expresses narrowly exclusive hope that leads to the embarrassment and shaming of other nations. Let us now proceed to Isaiah.

\section{Isaiah}

Pieter M Venter affirms the idea that during the time of the Second Temple there was a coexistence of both an exclusivist and an inclusivist ethos. ${ }^{59} \mathrm{He}$ argues that both are presented in the books of the Hebrew Bible ${ }^{60}$ reflecting the period of the late Second Temple. ${ }^{61} \mathrm{He}$ argues that the penitential prayers in Ezra 9:6-15 and Nehemiah 9:5b-37 propose a particularist view of God and an exclusivist identity for Israel. He continues and says:

\footnotetext{
54 Cf. Blenkinsopp, Judaism, 37.

55 Nehemiah 13:23.

56 Nehemiah 13:24.

57 Nehemiah 13:26.

58 Nehemiah 13:26-27.

59 Cf. also Williamson, 1 \& 2 Chronicles, 24.

60 He also includes non-canonical books.

61 Venter, Congruent Ethos, 12.
} 
In opposition and reaction to this stance a contradicting ethos of inclusivism is found in Isaiah 56-66, the story of Ruth, Jonah, Esther, Tobit, Judith and even Joshua. ${ }^{62}$ During the Second Temple period smaller groups showing an inclusivist trend in a variety of different forms opposed the exclusivist voice of the Zadokites. In Trito-Isaiah God's righteousness is extended to those foreigners and eunuchs who were formerly excluded from the Israelite community. ${ }^{63}$

In his article, Venter compares Ezra and Nehemiah on the one hand, and Daniel on the other. He concludes that the former proposes a particularist view of God and an exclusivist identity for Israel, as it has already been said. He also concludes that in all probability, the book of Daniel later followed the trend of the continuing voice of universalism by earlier inclusive books of the Second Temple in his apocalyptic view. ${ }^{64}$ Now, let us advance and examine the Isaiahan tradition culminating in an investigation of Isaiah 19:16-25 to confirm a universalist claim.

\section{The Isaiahan Tradition}

Concerning the Abrahamic promise, Blenkinsopp perceives in several references ${ }^{65}$ to the new people of God in Isaiah 40-55, the Abrahamic blessing interpreted by prophetic authority in the light of a new situation, viz. a confessional community with freedom to exercise a personal decision to adhere to the stipulations. ${ }^{66} \mathrm{He}$ sees the emergence of a confessional community as open on principle to outsiders. "One indication is the reinterpretation of the promise to Abraham to include proselytes". ${ }^{67}$ Grabbe observes that several passages in Isaiah 56-66 suggest a universalist view, rare if not unknown in preexilic times, especially $56: 3-7 .{ }^{68}$ This universalist view is the reason why this article favours Isaiah, and supports Blenkinsopp's remark, that: "In 56:1-7 the ethnic and physical disqualifications of the Deuteronomistic law (Deut. 23:2-9) are set aside in favour of a general statement about adherence to the covenant ratified by Sabbath observance". ${ }^{9}$ This contrasts to the Israelite identity in Ezra-Nehemiah which is primarily genealogical and thus the boundaries separating them are impermeable and without any doubt exclusivistic. ${ }^{70}$ Despite what has been said, the article admits that the Book of Isaiah does undeniably reflect particularist tendencies. Although this part of the discourse is beyond the scope of this article, I maintain that the conspicuous particularist tendencies in Isaiah do not nullify the universalistic nature of the book. Just to demonstrate this universalism, we briefly examine Isaiah 19:16-25 which Brueggemann categorises, together with Amos 9:7, as texts of radical hope. ${ }^{71}$ Interestingly, Isaiah 19:1-25 expresses both the particularistic and the universalistic views.

\footnotetext{
62 In this list I add Chronicles which was discussed extensively in my dissertation titled Identity Formation and Community Solidarity: Second Temple Historiographies in Discourse with (South) African Theologies of Reconstruction.

Venter, Congruent Ethos, 12, cf. also Moffat, Ezra's Social Drama, 168-169.

Congruent Ethos in the Second Temple Literature of the Old Testament, 2011.

Specifically 44:3-5.

Blenkinsopp, Isaiah 56-66, 83; Blenkinsopp, Prophet of Universalism, 86.

Blenkinsopp, Prophet of Universalism, 92.

Grabbe, Judaism, 47.

Blenkinsopp, Isaiah 56-66, 83.

Venter Congruent, 9.

Brueggemann, Theology, 520.
} 
Isaiah 19:16-25

Brueggemann titles the whole chapter, Isaiah 19, Egypt Devastated and Blessed. ${ }^{72}$ Isaiah 19:1-15 prophesies about Egypt: the collapse of civil order (1-4), the destruction of the basis of life (5-10) and the helplessness and inability to act (11-15). ${ }^{73}$ Isaiah 19:16-25 prophesies about: Egypt under the terror of God (16-17), five cities in Egypt subject to Yahweh (18), the conversion of Egypt (19-22), the highway from Egypt to Syria (23) and the blessed community of nations (24-25). ${ }^{74}$ Isaiah 19:16-25 is demarcated by the phrase "on that day" into five sections. ${ }^{75}$ The most interesting thing about the phrase is that it refers to the day of judgement for Egypt that has been portrayed in 19:1-15. The debate on the date of Isaiah 19:16-25 is inconclusive, but that does not affect the discernment of its theological essence. John FA Sawyer argues that "19:16-25 appears to build on earlier intimations of universalism, many of them Isaianic..." One of the things that modern commentators agreed about, according to Sawyer, is that this passage "represents some kind of high point in the Old Testament ... [being] ${ }^{76}$ 'the most universal and missionary of all Isaiah's prophecies"," 77

Concluding 19:1-15 and introducing 19:18-25, 19:16-17 states that on the day of judgement for Egypt “... the land of Judah will become a terror to Egypt ... because of the plan of Yahweh of hosts that He is planning against him". Commenting on this section, Brueggemann remarks that "what had been a Yahwistic, theological claim is made to be a political assertion for Judah. ${ }^{78 "}$ "Here the article fully agrees with Göran Eidevall when he says: "it would seem that the references in this text to the rule of YHWH are intimately linked to a particularist - and imperialist - vision of future Jerusalem-centred world dominion. ${ }^{79}$ " In the second section, verse 18 introduces a turnabout move. Despite all the various interpretations of verse $18 \mathrm{~b}$, one thing is certain: "No negative connotations seem to be attached to the use here of the expression "Canaan." 80 This is in the direction of tolerance. In this expression the article discerns a universalistic tendency, even to the extent that it appears like ridicule of the particularist agenda. On that same day, according to the next section, verse 19-22, "Yahweh will strike Egypt, striking and healing; and they will return to Yahweh, and he will respond to their prayer, and he will heal them". Otto Kaiser remarks as follows: "...the blows which are to fall upon the Egyptians are seen as leading not as formerly to their death, but to their conversion and therefore to their life. ${ }^{81}$ "

\footnotetext{
Brueggemann, Isaiah 1-39, 155.

Kaiser, Isaiah 13-39, 100-103.

Kaiser, Isaiah 13-39, 105-112.

Isaiah 9:16-17, 18, 19-22, 23 \& 25.

Cf. Kaminsky, Election Theology, 37.

77 Sawyer, Blessed be my People, 57. Joel S Kaminsky argues that Sawyer's claim is a distortion that emanates from the perception held by Anthony Gelston (Gelston, 'Universalism', 396) and other contemporary scholars that the universal offer of the experience of salvation is the highest form of universalism and the most progressive and tolerant. Moreover he argues that this may be due to "its strong resonance with Christian missionary outreach. In this view, the spread of Christianity is seen as a fulfilment of this prophecy, in spite of the fact that the larger context speaks explicitly of sacrificial worship (v. 21) as well as specifically of Assyrians and Egyptians" (Kaminsky, Election Theology, 37). This paper appreciates Sawyer's observation and that it regards this passage in its own context as progressive and tolerant. It is the kind of spirituality that needs to be emulated in our time.
} 
Blenkinsopp sees this "as a reinterpretation of the anti-Egyptian poem". ${ }^{22}$ Undoubtedly, this is a blow to the particularist agenda reflected in 19:1-17. Still, "on that day, there will be a highway from Egypt to Assyria, and Assyria will come into Egypt, and Egypt into Assyria, and Egypt will worship together with Assyria. ${ }^{83 "}$ Here, Assyria is included in the hope of salvation. "The new road bespeaks a new peaceableness among the nations." ${ }^{85}$ In a climatic fashion, verses 24-25 claim that on that very same day:

Israel will be the third with Egypt and Assyria, a blessing in the midst of the earth, whom Yahweh of hosts blessed, saying, 'May Egypt my people be blessed, and Assyria, the work of my hands, and my inheritance, Israel'.

Notwithstanding various date speculations for verses 23-25, Brueggemann maintains, “...it is a piece of Israel's testimony concerning the future of the nations under the sovereignty of Yahweh." 86 Blenkinsopp is specific, saying that here is seen how the Isaiahan tradition served as one of the most powerful vectors of the broader and more inclusive way of thinking about God's saving purpose for the world throughout the period of the Second Commonwealth. ${ }^{87}$ Here "there is no longer a narrowly exclusive hope of salvation of Israel only when other nations are enslaved and put to shame." 88 "By this astonishing renaming, the enemies are renamed as fellow members of the covenant and are invited to accept new identity in the world. But we also notice that to make this possible, Israel must relinquish its exclusive claims and its unrivalled relation to Yahweh and be willing to share the privilege of such identity. ${ }^{89}$ " Having examined two interpretations of the Abrahamic covenant during the post-exilic era, we continue to explore post-biblical interpretations of the Abrahamic promise. Specifically, let us explore the colonial era.

\section{Fulfilment of Land Promise in Colonial Times}

Examining the subsequent reading of the biblical theme of the land promise and its fulfilment in colonial times is an inexhaustible exercise. In order to render this discussion intelligible some demarcation must take place, so this part of our discussion will examine the possibility of an interface between the land promise in the Old Testament and the acquisition of land during colonisation. This section is cursory because it functions only to demonstrate and reinforce the point to be made. According to Michael Prior there is abundant evidence pointing to links between the biblical narratives of land and colonial exploitation of indigenous peoples. ${ }^{90} \mathrm{He}$ further remarks that at the level of reception, the biblical land traditions have fueled virtually every form of militant colonialism emanating from Europe, resulting in the suffering of millions of people. ${ }^{91}$ Earlier in his book titled The Bible and Colonialism: A Moral Critique, he presents the use of biblical narratives of the Promised Land in different colonisation ventures by Spain in Latin America, Holland and

\footnotetext{
Blenkinsopp, Isaiah 1-39, 317.

Isaiah 19:23.

Kaiser, Isaiah 13-39, 109.

Brueggemann, Isaiah 1-39, 164.

Brueggemann, Theology, 521.

Blenkinsopp, Isaiah 1-39, 320.

Kaiser, Isaiah 13-39, 110.

Brueggemann, Isaiah 1-39, 166.

Prior, A land Flowing with Milk, 7.

91 Prior, A land Flowing with Milk, 17.
} 

the British Empire in South Africa and Israel in Palestine. ${ }^{92}$ He then compares these colonial enterprises with the Old Testament Conquest. While these are different and unique socio-historical contexts he still finds some common denominators. The first is that the colonisers portrayed themselves as chosen or privileged people. The second is that they also portrayed themselves as racially superior. The third is the enslavement of the indigenous people. The fourth is that the colonisation was religiously motivated. The last one is that the conquered land was uninhabited or habitation was irregular (with the exception of Spain in this regard). Concerning the first and the fourth common denominators, for example, $\mathrm{T}$ Dunbar Moodie reports that by 1938 "most Afrikaners believed that they belonged to an elect People,..." Referring to the Broederbond, ${ }^{93}$ he says a prospective member "was informed that ... the Afrikaner nation with its own character and task was called into being in this land by the hand of God, and is destined to exist as long as God so wishes. ${ }^{94 "}$ On the Great Trek, ${ }^{95}$ he states that they were followed by the British army, like that of Pharoah, and everywhere were beset by the unbelieving black 'Canaanites' but, by acting according to God's will, He delivered them out of the hand of their enemies and gave them their freedom in the promised land. The most crucial point for our discussion however, is the exclusivity that characterised this process. Prior further states that the nationalist origin myth of the Great Trekkers claims:

... the Bible served as the source of Boer identity, and that as they trekked, the Boers considered themselves to be chosen people, rescued from Egypt (British oppression), on their way to the promised land. The indigenous black people were the 'Canaanites who served foreign gods, whom 'Israel' should not marry. ${ }^{96}$

This kind of reading and application of the Old Testament land promise narrative resembles the amalgamation theological strategy discussed above. Brueggemann describes it as the ideology of entitlement. ${ }^{97}$ It proceeds on the basis of the primal promises of Genesis 12-36 to assume entitlement to the land without regard for any other inhabitants, including those who may have been there prior to Israel's emergence. ${ }^{98}$ It has led to social conflict. Many lives were lost and this article propounds that ethically it cannot be encouraged. On that note, let us proceed to our conclusion.

\section{Conclusion}

The question is whether the fulfilment of the land promise in the OT can be a source of hope for communities in (South) Africa. It has been argued that this theme is so important to the Old Testament that Israel's national identity became inextricably intertwined with it. This article affirmed that the descendants of Abraham found hope in the fulfilment of the promise of the land in the Old Testament. However, the question, "who are the descendants of Abraham" still had to be resolved. This article concludes that the Babylonian exiles won the contestation of who were Abraham's descendants and excluded everyone else. They

\footnotetext{
Prior, The Bible and Colonialism, 48-213.

It was a secret, exclusively male and Afrikaner Calvinistic organisation in South Africa dedicated to the advancement of Afrikaner interests.

94 Moodie, The Rise, 103.

95 It was a movement of Afrikaners up into the interior of southern Africa in search of land where they could establish their own homeland, independent of British rule.

97 Brueggemann, The Land, 2002:xv.

98 Brueggemann, The Land, 2002:xiv.
} 
employed a theological strategy called amalgamation. From the discussion, it became clear that the waiting on the Lord of the exiles in its amalgamation form is based on a narrowlydefined exclusive hope that leads to the embarrassment and shaming of other nations. For that reason we argue that it cannot be a source of hope for Christian communities in (South) Africa. This became even more apparent when it turned out that the application of the Old Testament land promise narrative by the colonialists resembled the amalgamation theological strategy. At this realisation the article explored alternative theological strategies to make sense of the land promise to Abraham. Specifically the Book of Isaiah became the object of this venture. Isaiah 19:16-25 was therefore probed and the result delivered the opposite of the amalgamation strategy. Isaiah 19:16-25 exhibits a universalistic and inclusive nuance that presents God's redemptive blessings as available for all peoples, regardless of ethnicity. It is a theological strategy this article promotes that can render the promise a source of hope for all Christian communities in (South) Africa.

It seems appropriate to conclude by quoting Blenkinsopp: "If Ezra had been successful, Ruth the Moabitess would never have married Boaz, Achior the Ammonite ${ }^{99}$ would never have been accepted into Judaism, and Jonah would have been saved a great deal of trouble and embarrassment". ${ }^{100}$ Such having been said, it might be fruitful for us to take note of Grabbe's remark in this regard, namely:

We know what the books of Ezra-Nehemiah want us to believe. We know what the story is that they want to tell, and that story has validity in its own right, as theology and literature. It is perfectly legitimate to read the books from a theological point of view, following the dominant theme and message. The metaphor of exile/return/successagainst-great-odds has been a powerful symbol for Judaism through the ages, helping the Jews to sustain their identity and hope through many dark, oppressive centuries. The Hebrew Ezra-Nehemiah has been a vital support in keeping this central symbol alive. Nevertheless, we do not have to make that story our own. We can ignore it or even disagree with it. ${ }^{101}$

This reminds me of Gale Yee saying "the Bible was not written to be an object of aesthetic beauty or contemplation, but as a persuasive force forming opinion, making judgments, and exerting change. It was a form of power acting upon the world". ${ }^{102}$ If I may copy Grabbe's format; this article is aware of what the Book of Isaiah is trying to teach the world. We know what it is that it wishes to denounce: it is the violation of human rights and dehumanisation that can be generated by the particularistic amalgamation theological strategy. Robert Warrior indicates that even if we could correct historical facts in the narratives, it would still not resolve the narrative problem. People who read the narratives read them as they are, not as scholars and experts would like them to be read and interpreted. History is no longer with us but the narrative remains. ${ }^{103}$ To adapt Rannfrid I Thelle's statement therefore, the fact is that there are other, much more 'humane' tendencies in the Old Testament that contradict the tough stance of the amalgamation theological strategy, and which may leave interpreters with a choice about what they wish

\footnotetext{
99 Judith 14:10.

100 Blenkinsopp, Judaism, 145.

101 Grabbe, Ezra-Nehemiah, 192. In similar fashion, Carol J Dempsey argues that "the experience of God and the interpretation of God's ways as represented in the prophetic texts is historically, socially, culturally and theologically conditioned and remain so throughout the biblical text as a whole and in contemporary times as well" (2000:2).

102 Yee, The Author, 116.

103 Warrior, Canaanites, 3.
} 

to emphasise. This article emphasises a universalistic, inclusivistic view over against the particularistic, exclusivistic one. In it, the fulfilment of the land promise in the OT can be a source of hope for all communities in (South) Africa.

\section{BIBLIOGRAPHY}

Allen, \& Laniak, TS 2003. Ezra, Nehemiah, Esther. Peabody: Hendrickson Publishers. Birch, BC 1997. Hosea, Joel and Amos. Louisville: Westminster John Knox Press.

Blenkinsopp, J 1988. "Second Isaiah-Prophet of Universalism" in Journal for the Study of the Old Testament, 83-103.

Blenkinsopp, J 2000. Isaiah 1-39: A New Translation with Introduction and Commentary. New York: Doubleday.

Blenkinsopp, J 2003. Isaiah 56-66: A New Translation with Introduction and Commentary. New York: Doubleday.

Blenkinsopp, J 2009. Judaism, The First Phase: The Place of Ezra and Nehemiah in the Origins of Judaism. Grand Rapids: Eerdmans.

Brueggemann, W 1979. Trajectories in Old Testament Literature and the Sociology of Ancient Israel in Journal of Biblical Literature, Vol. 98, No. 2:161-185. The Society of Biblical Literature. http://www.jstor.org/stable/3265508. Accessed on 05/02/2015.

Brueggemann, W 1986. Hopeful Imagination: Prophetic Voices in Exile. Philadelphia: Fortress Press.

Brueggemann, W 1997. Theology of the Old Testament: Testimony, Dispute, Advocacy. Minneapolis: Augsburg Fortress.

Brueggemann, W 1998. Isaiah 1-39. Louisville: John Knox Press.

Brueggemann, W 2002. The Land: Place as Gift, Promise, and Challenge in Biblical Faith. Minneapolis: Fortress Press.

Cezula, NS 2013. Identity Formation and Community Solidarity: Second Temple Historiographies in Discourse with (South) African theologies of reconstruction. Unpublished Dissertation. Stellenbosch University.

Eidevall, G 2009. Prophecy and Propaganda: Images of Enemies in the Book of Isaiah. Winona Lake: Eisenbrauns.

Gelston, A 1992. "Universalism in Second Isaiah" in The Journal of Theological Studies, Vol. 43, No. 2:377-398. http://www.jstor.org/stable/23963896 .Accessed: 23/02/2015.

Grabbe, LL 1998. Ezra-Nehemiah. London: Routledge.

Grisanti, MA 1998. "Israel's Mission to the Nations in Isaiah 40-55: An Update" in The Master's Seminary Journal 9/1:39-61.

Hawtrey, KM 1993. "The Exile as a Crisis for Cultic Religion: Lamentations and Ezekiel” in The Reformed Theological Review, vol. 52, no. 2:74-83.

Henderson, DW 2015. Tranquility: Cultivating a Quiet Soul in a Busy World. Grand Rapids: Baker Books, 157-167. 
Jonker, LC 2008. "Who constitutes Society? Yehud's self-understanding in the Late

Persian Era as reflected in the Books of Chronicles" in Journal of Biblical Literature 127/4:703-724.

Kaiser, O 1974: Isaiah 13-39: A Commentary. London: SCM Press.

Kaiser, WC Jr 1981. "The Promised Land: A Biblical-Historical View" in Bibliotheca Sacra 138:302-12. Dallas Theological Seminaryhttp://faculty.gordon.edu/hu/bi/ted hildebrandt/otesources/01genesis/text/articles-books/kaiser_promisedland_bsac.pdf, 29/07/2014.

Kalimi, I 2012. "In the Persian Period: New Perspectives on Ezra-Nehemiah" in New Perspectives on Ezra-Nehemiah: History and Historiography, Text, Literature, and Interpretation (Editor Kalimi, I). Winona Lake, Eisenbrauns, 1-8.

Kaminsky JS 2011. "Election Theology and the Problem of Universalism" in Horizons in Biblical Theology 33:34-44.

Kessler, J 2006. "Persia's Loyal Yahwists: Power Identity and Ethnicity in Achaemenid Yehud" in Judah and the Judeans in the Persian Period (eds. O Lipschits \& M Oeming). Winona Lake: Eisenbrauns, 91-121.

Lamp, JS 2000. "Hope" in Eerdmans Dictionary of the Bible (ed. DN Freedman). Grand Rapids: Eerdmans, 605-606.

Lemche, NP 1991. The Canaanites and their Land. Sheffield: Sheffield Academic Press, 123-149.

McCarter, PK Jr 2000. “Abraham” in Eerdmans Dictionary of the Bible (ed. DN Freedman). Grand Rapids: Eerdmans, 8-10.

Moffat, DP 2013. Ezra's Social Drama: Identity Formation, Marriage and Social Conflict in Ezra 9 and 10. New York Bloomsberry: T\&T Clark.

Moodie, TD 1975. The Rise of Afrikanerdom. Los Angeles: University of California Press.

Mulzac, KD 2000. "Remnant" in Eerdmans Dictionary of the Bible (ed. DN Freedman). Grand Rapids: Eerdmans, 1117-1118.

Phelps, MA. 2000. "Midian" in Eerdmans Dictionary of the Bible (ed. DN Freedman). Grand Rapids: Eerdmans, 896.

Prior, Michael 1997. The Bible and Colonialism. A Moral Critique. Sheffield Academic Press: Sheffield.

Prior, Michael 2003. A Land flowing with Milk, Honey and Palestinians. Ethnic Cleansing and the Bible. http://www.corkpsc.org/db.php?aid=1787. Accessed 21/01/2015.

Reumann, J 2000. "Faith" in Eerdmans Dictionary of the Bible (ed. DN Freedman). Grand Rapids: Eerdmans, 453-454.

Rom-Shiloni, D 2011. "From Ezekiel to Ezra-Nehemiah: Shifts of Group Identities within Babylonian Exilic Ideology" in Judah and the Judeans in the Achaemenid Period: Negotiating Identity in an International Context (eds. O Lipschits, GN Knoppers \& M Oeming).Winona Lake: Eisenbrauns. 127-151.

Sawyer, JFA 1986. "Blessed be my People Egypt (Isaiah 19:25): The Context and Meaning of a Remarkable Passage" in A Word in Season: Essays in Honour of William McKane (eds. Martin JD \& Davies PR). Sheffield: JSOT Press, 57-71.

Simkins, RA 2000. "Worldview" in Eerdmans Dictionary of the Bible (ed. DN Freedman). Grand Rapids: Eerdmans, 1387-1389. 
Smith-Christopher, DL 2000. "Exile" in Eerdmans Dictionary of the Bible (ed. DN Freedman). Grand Rapids: Eerdmans. 439-440.

Snyman, F 2010. "Reading the Patriarchal Narratives (Gen. 12-50) in the Context of the Exile" in Nederduitse Gerefomeerde Teologiese Tydskrif. http://ngtt.journals.ac.za

Thelle, RI 2007. "The Biblical Conquest Account and Its Modern Hermeneutical Challenges" in Studia Theologica, Vol.61, Issue: 1:61-81.

Van Seters, J 1975. Abraham in History and Tradition. New Haven: Yale University Press.

Venter, PM 2011. "Congruent Ethos in the Second Temple Literature of the Old Testament” in HTS Teologiese Studies/Theological Studies 67(1), Art. \#965, 13 pages. DOI:10.4102/hts.v67i1.965

Waltke, BK 2008. "Fundamentals of Preaching the Book of Proverbs, Part 2" in Bibliotheca Sacra 165:131-144.

Warrior, R 1991. "A Native American Perspective: Canaanites, Cowboys, and Indians" in Voices from the Margin: Interpreting the Bible in the Third World (ed. RS Sugirtharajah). Maryknoll: Orbis Books, 287-295.

Weisman, Z 1985. "National Consciousness in the Patriarchal Promises" in Journal for the Study of the Old Testament 31:55-73.

Wenham, GJ 1994. "Genesis” in New Bible Commentary: 21 st Century Edition (4th edition). Leicester: Inter-Varsity Press.

Williamson, HGM 1982. 1 and 2 Chronicles. New Century Bible Commentary; London: Marshall Morgan \& Scott.

Wills, LM 2008. Not God's People: Insiders and Outsiders in the Biblical World. Lanham: Rowman \& Littlefield Publishers.

Wimmer, JF 2000. "Promise" in Eerdmans Dictionary of the Bible (ed. DN Freedman). Grand Rapids: Eerdmans, 1085.

Yee, Gale A 1995. "The Author/Text/Reader and Power: Suggestions for a Critical Framework for Biblical Studies" in Reading from this Place, Volume 1: Social Location and Biblical Interpretation in the United States. (eds. Fernando F. Segovia and Mary Ann Tolbert). Minneapolis: Fortress Press, 109-118. 